Ірина Володимирівна Атаманчук, кандидат юридичних наук, доцент Донецького національного університету імені Василя Стуса*

ORCID: 0000-0002-1931-0194

Юрій Іванович Ковальчук, кандидат юридичних наук, доцент Київського університету права НАH України**

ORCID: 0000-0003-4271-0572

\title{
МЕЖІ РОЗУМІННЯ ПОНЯТЬ «ЗАРОБІТОК» І «ДОХІД» У КОНТЕКСТІ ПРАВОЗАСТОСУВАННЯ У ВІДНОСИНАХ СТЯГНЕННЯ АЛІМЕНТІВ
}

Постановка проблеми. На шляху до Свропейського Союзу для української держави надзвичайно актуальними $є$ вирішення проблем реалізації кожною дитиною права на виховання в сім’ї, зростання в безпечному сімейному оточенні, підвищення ефективності роботи державних органів та органів місцевого самоврядування із запобігання соціальному сирітству, вдосконалення системи надання соціальних послуг дітям $\mathrm{i}$ сім'ям $з$ дітьми, забезпечення рівня життя, достатнього для фізичного, інтелектуального, морального, культурного, духовного і соціального розвитку дитини. Саме тому протягом останніх років правотворці приділяли значну увагу сфері ефективного регулювання аліментних правовідносин в аспекті посилення захисту прав дитини. Так, за минулі роки, з метою удосконалення регулювання відносин стягнення аліментів, було прийнято: Закон України «Про внесення змін до деяких законодавчих актів України щодо посилення захисту права дитини на належне утримання шляхом вдосконалення порядку примусового стягнення заборгованості зі сплати аліментів» від 07 грудня 2017 р., Закон України «Про внесення змін до деяких законодавчих актів України щодо створення економічних передумов для посилення захисту права дитини на належне утримання» від 03 липня 2018 р., Закон України «Про внесення змін до деяких законів України щодо посилення соціального захисту осіб, які доглядають за хворими дітьми» від 03 липня 2018 р., Закон України «Про внесення змін до Податкового кодексу України» від 03 липня 2018 р., якими було змінено порядок стягнення аліментів та збільшено їх розмір; запроваджено нові механізми притягнення недобросовісних платників аліментів до відповідальності; посилено захист дітей-сиріт та дітей, позбавлених батьківського піклування. Результати внесення змін до чинного законодавства знайшли своє відображення у судовій практиці та привернули посилену увагу юридичної спільноти до аналізу ефективності правозастосування прийнятих нормативних актів та вирішення проблем ухилення від сплати аліментів, приховання платниками аліментів доходів $з$ метою зменшення суми платежу, неправильного розрахунку аліментів. Попри законодавчі новації, одним із суперечливих питань аліментних відносин залишається відсутність єдиного підходу до розуміння понять «заробіток» $\mathrm{i}$ «дохід» у процесі правозастосування норм постанови Кабінету Міністрів України № 146 «Про перелік видів доходів, які враховуються при визначенні розміру аліментів на одного з подружжя, дітей, батьків, інших осіб» від 26 лютого 1993 р. (далі - Постанова КМУ № 146), що тягне за собою виникнення спірних питань при здійсненні розрахунку аліментів.

У цій статті зроблено спробу проаналізувати поняття «заробіток» $\mathrm{i}$ «дохід», що традиційно належать до галузевих категорій трудового та податкового права, крізь призму сімейного законодавства, у відносинах стягнення аліментів. Враховуючи, що сімейне законодавство регулює аліментні відносини різні за своїм

(C) І.В. Атаманчук, Ю.І. Ковальчук, 2019

* Irina Atamanchuk, Ph.D., Associate Professor of Vasyl'Stus Donetsk National University

** Yuriy Kovalchuk, Ph.D., Associate Professor of Kyiv University of Law of the NAS of Ukraine 
суб’єктним складом, як і Постанова КМУ № 146, ми приділяємо першочергову увагу аналізу понять «заробіток» і «дохід» через фокус нормативної бази з регулювання захисту прав дітей, оскільки вважаємо, що у нашому суспільстві проблема належного матеріального забезпечення дітей стоїть найбільш гостро. На сьогодні сфера правового регулювання аліментних відносин має ще багато проблемних питань, які потребують подальшого дослідження та наукового аналізу. Серед них: питання правового розуміння понять «заробіток» i «дохід» у контексті правозастосування у відносинах стягнення аліментів.

Аналіз останніх досліджень і публікацій. Теоретичні дослідження аліментних правовідносин здійснювались здебільшого у рамках сімейного права такими науковцями, як С.С. Алєксєєв, Т.В. Бондар, О.П. Віхрова, Л.С. Гузь, А.В. Гузь, О.В. Дзера, М.М. Дякович, І.В. Жилінкова, О.С. Іоффе, Л.П. Короткова, С.М. Лепех, Г.К. Матвєєва, О.М. Нечаєва, В.П. Нікітіна, З.А. Підопригора, З.В. Ромовська, Є.О. Харитонов, Ю.С. Червоний, Я.М. Шевченко та ін.

Вузько спрямовані дослідження здійснювали: I.M. Чістякова, яка проаналізувала особливості розгляду судових справ щодо стягнення аліментів на дитину за участю іноземних громадян ${ }^{1}$; С. Ханович розглянула порядок стягнення аліментів на дитину за чинним законодавством та зробила висновок про взаємозв’язок норм сімейного права, що регулюють порядок стягнення аліментів 3 нормами виконавчого, податкового, адміністративного та кримінального законодавства2; С.В. Перун проаналізувала зміни до Сімейного кодексу України щодо сплати аліментів на дитину, нові розміри, порядок нарахуванняз; Л.Я. Свистун охарактеризувала правове регулювання стягнення аліментів на дітей та виділила проблеми законодавчого регулювання нарахування та стягнення аліментів ${ }^{4}$.

I. Апопій здійснила аналіз новел вітчизняного законодавства щодо правового режиму аліментів, встановлення гарантованого і рекомендованого мінімального розміру, обставин, які враховуються для визначення розміру аліментів, судового розгляду справи про стягнення аліментів і законодавчих гарантій примусового стягнення 5 . Свої дисертаційні дослідження присвятили аліментним відносинам Л.В. Афанасьєва «Аліментні правовідносини в Україні», 2003 р.; М.Б. Мельник «Припинення аліментних зобов’язань набуттям дитиною майна: загальнотеоретичне дослідження», 2019 рік.

У виданому Національною асоціацією адвокатів України Дайджесті правових позицій Верховного Суду у правових спорах за 1 півріччя 2019 р. окрему увагу приділено питанням судової практики нарахування пені за заборгованість зі сплати аліментів; питанням утримання повнолітньої дитини 6 .

Формулювання мети статті. Метою статті є вироблення пропозицій удосконалення практики правозастосування при здійсненні розрахунку аліментів на базі правового аналізу понять «заробіток» і «дохід» у контексті правозастосування у відносинах стягнення аліментів.

Виклад основного матеріалу. На сьогодні в національній правовій науці існують різні, здебільшого галузеві, підходи до розуміння меж змістовного наповнення понять «заробіток» і «дохід», оскільки вони базуються на тлумаченні змісту актів законодавства, що належать до відповідної правової галузі: трудового, податкового, виконавчого, цивільного та сімейного права. Також певні тлумачення можна побачити у міжнародних правових актах, ратифікованих в Україні. У Сімейному кодексі України (далі - СК України) пряме тлумачення понять «заробіток» і «дохід» відсутнє. За нормами сімейного законодавства обов'язок сплачувати аліменти виникає у матері, батька, інших членів сім’ї та родичів з обов'язку утримувати дитину, у повнолітніх дочки, сина інших повнолітніх членів сім’ї та родичів з обов'язків утримувати батьків та інших родичів. Розрахунок суми аліментів залежить від підстав виникнення аліментних зобов'язань: чи встановлені аліменти батьківською угодою, чи присуджені судом. Аліментні платежі на дитину можуть бути визначені у частці від заробітку (доходу) та у твердій грошовій сумі (ст. 183, ст. 184 СК України). У ч. 1. ст. 183 СК України вказано, що частка заробітку (доходу) матері, батька, яка буде стягуватися як аліменти на дитину, визначається судом. А суд керується положеннями Постанови КМУ № 146, що визначає перелік видів доходів, які враховуються при визначенні розміру аліментів на одного з подружжя, дітей, батьків, інших осіб.

На основі аналізу положень Постанови КМУ № 146 можна визначити порядок формування суми, від якої починається розрахунок суми аліментів. У п. 1 вказується, що утримання аліментів 3 працівників провадиться з усіх видів заробітку і додаткової винагороди як за основною роботою, так і за роботою за сумісництвом, далі йде невичерпний перелік з 19 підпунктів, що закінчується підпунктом «19) інших видів заробітку». I тут уповноваженим органам потрібно надати відповідь на питання: які доходи особи відносять до інших видів заробітку і їх потрібно враховувати до суми з якої здійснюється утримання аліментів, а які ні, чи мають аліменти утримуватися також і з інших видів доходів не вказаних у переліку, таких, наприклад, як виплата учаснику ТОВ його частини у зв'язку з його виходом з товариства. Подібне проблемне питання виникло у справі за позовом про перерахунок заборгованості з аліментів, стягнення неустойки, за касаційною скаргою на рішення Ніжинського міськрайонного суду від 14 листопада 2007 р. та ухвалу апеляційного суду Чернігівської області від 15 січня 2008 р., виконавчою службою не утримувалися аліменти 3 дивідендів на частку майна відповідача як співвласника ТОВ, оскільки виконавча служба не включила їх до видів заробітку. Відповідно до змісту Ухвали Колегії суддів Судової палати у цивільних справах Верховного Суду від 09 квітня 2008 р., колегія суддів, розглянувши цю справу, дійшла висновку про неправильне застосування судами нижчестоящих інстанцій положень пп. 19 п. 1 Постанови КМУ № 146 та роз'яснила, що утримання аліментів з працівників провадиться з усіх видів заробітку і додаткової винагороди як за основною роботою, так і за роботою за сумісництвом, в тому числі з інших видів заробітку, а дивіденди є одним із видів доходу батька дитини, а тому твердження суду про те, що з дивідендів аліменти не можуть утримуватися, є помил- 
ковим 7 . 3 наведеного прикладу можна визначити потребу індивідуальної конкретизації норм 3 регулювання аліментних зобов'язань, виходячи з обставин кожної конкретної ситуації у справі. Подібного висновку доходить Л.Я. Свистун, яка вважає, що суд має брати до уваги всі обставини справи, досліджуючи джерела прибутку особи, з якої будуть стягуватися аліменти на дитину, враховувати наявність нерухомого майна, транспортного засобу, земельних ділянок, тобто реальний рівень його житття 8 .

Такі твердження збігаються з висновками Верховного Суду, викладених у правовій позиції Постанови по справі № 346/103/17 від 23 січня 2019 р., при встановленні потреби в утриманні повнолітньої дитини суд повинен враховувати всі джерела, що утворюють ії дохід, обов'язок обох батьків із надання відповідної матеріальної допомоги та спроможність останніх їі надавати ${ }^{9}$.

За своєю правовою природою поняття «заробіток» наближене до поняття «заробітна плата» тому вони часто ототожнюються. Згідно з ст. 94 Кодексу законів про працю України (далі - КЗпП України), заробітна плата - це винагорода, обчислена, як правило, у грошовому виразі, яку власник або уповноважений ним орган виплачує працівникові за виконану ним роботу. Тотожне визначення містить ст. 1 Закону України «Про оплату праці», а у ст. 2 цього Закону визначені складові структури заробітної плати: основна, додаткова заробітна плата, інші заохочувальні та компенсаційні виплати, що розширює тлумачення поняття «заробітна плата».

Аналіз змісту КЗпП України, положень Закону України «Про оплату праці», розробленої на його базі Інструкції зі статистики заробітної плати дає можливість стверджувати, що у П. 1 Постанови КМУ № 146 поняття «заробіток» вживається саме у контексті поняття «заробітна плата», на що вказує термін «працівників», притаманний трудовим відносинам, тобто платник аліментів у п. 1 Постанови розглядається у якості суб'єкта трудових відносин, при цьому Постанова включає до поняття «заробітку» виплати, які заробітною платою не $\epsilon$, що свідчить про широке тлумачення змісту поняття «заробіток». Конвенція Міжнародної організації праці «Про захист заробітної плати» № 95, ратифікована 30 червня 1961 р., у ст. 1 закріплює, що відповідно до мети цієї Конвенції термін «заробітна плата» означає, незалежно від назви й методу обчислення, будь-яку винагороду або заробіток, які можуть бути обчислені в грошах і встановлені угодою або національним законодавством, що їх роботодавець повинен заплатити на підставі письмового або усного договору про наймання послуг, працівникові за працю, яку виконано чи має бути виконано, або за послуги, котрі надано чи має бути надано. Тобто, поняття «заробіток» включається до більш широкого поняття «заробітна плата».

У ст. 117 КЗПП України зустрічається таке поняття, як «середній заробіток» в контексті компенсаційної виплати за час затримки розрахунку при звільненні, тому можна стверджувати про різнорідне змістовне наповнення поняття «заробіток» в аліментних правовідносинах та «середній заробіток» у трудових.

3 назви Постанови витікає віднесення заробітку до видів доходів, а у п. 13 вказується, що утримання аліментів провадиться з суми заробітку (доходу), що належить особі, яка сплачує аліменти, після утримання 3 цього заробітку (доходу) податків. Поняття «дохід» вживається у дужках після поняття «заробіток», що може розумітися як синонім чи вказівка на розділовий сполучник «або».

М. Шумило, розглядаючи проблеми застосування поняття «заробітної плати», на підставі аналізу двох правових позицій Верховного Суду України у справах № 6-1121цс16 та № 6-1395цс16 вказує, що на сьогодні у судовій практиці зберігають чинність дві правові позиції Верховного Суду України, в яких сформульовано різні підходи щодо тлумачення поняття «заробітна плата» («широкий» та «вузький»). Він висловлює думку, що при визначенні межі тлумачення терміна «заробітна плата» необхідно виходити передусім 3 позиції функціонального навантаження цієї виплати в трудовому законодавстві ${ }^{10}$.

У Податковому кодексі України (далі - ПК України) поняття «дохід» вживається у економічному сенсі під кутом визначення об'єктів оподаткування, тому до доходів включаються проценти, заробітна плата та інші види винагород. Так, у п. 14.1.54. ст. 14 (визначення понять) зазначено, дохід з джерелом їх походження з України - будь-який дохід, отриманий резидентами або нерезидентами, у тому числі від будь-яких видів їх діяльності на території України (включаючи виплату (нарахування) винагороди іноземними роботодавцями), iї континентальному шельфі, у виключній (морській) економічній зоні, у тому числі, але не виключно, доходи у вигляді: а) процентів, дивідендів, роялті та будь-яких інших пасивних (інвестиційних) доходів, сплачених резидентами України; б) доходів від надання резидентам або нерезидентам в оренду (користування) майна, розташованого в Україні, включаючи рухомий склад транспорту, приписаного до розташованих в Україні портів; в) доходів від продажу рухомого та нерухомого майна, доходів від відчуження корпоративних прав, цінних паперів, у тому числі акцій українських емітентів; г) доходів, отриманих у вигляді внесків та премій на страхування і перестрахування ризиків на території України; г) доходів страховиків - резидентів від страхування ризиків страхувальників - резидентів за межами України; д) інших доходів від діяльності, у тому числі пов'язаних 3 повною або частковою переуступкою прав та обов'язків за угодами про розподіл продукції на митній території України або на територіях, що перебувають під контролем контролюючих органів (у зонах митного контролю, на спеціалізованих ліцензійних митних складах тощо); е) спадщини, подарунків, виграшів, призів; є) заробітної плати, інших виплат та винагород, виплачених відповідно до умов трудового та цивільно-правового договору; ж) доходів від зайняття підприємницькою та незалежною професійною діяльністю. У розділі IV ПК України, що має назву «Податок на доходи фізичних осіб», п. 162.1.1. ст. 162, вказано, що платниками податку є фізична особа - резидент, яка отримує доходи як 3 джерела їх походження в Україні, так і іноземні доходи. Таким чином, законодавець надає широку структуру поняттю «дохід».

Дещо інше змістовне наповнення поняттю «дохід» надає Цивільний кодекс України (далі - ЦК України), поняття «дохід» як правова категорія входить до глави 13 «Речі. Майно», ч. 1 ст. 189 «Продукція, плоди 
та доходи», визначає що, продукцією, плодами та доходами є все те, що виробляється, добувається, одержується з речі або приноситься річчю, а ст. 192 з гл. 13 відносить до речей, майна гроші (грошові кошти). Таким чином, згідно з ЦК України проценти за розміщення коштів на депозитних рахунках є доходом від майна, але при цьому дещо спірне питання про можливість застосування до відносин примусового стягнення аліментів норм ЦК України з огляду на положення ч. 2 ст. 1 ЦК України.

Виникнення, зміни чи припинення аліментних правовідносин є сферою нормативного регулювання сімейних майнових прав та обов'язків з утримання, саме тому вважаємо, що контекст понять «заробіток» $\mathrm{i}$ «дохід» в питанні нарахування аліментів доцільно розглядати крізь призму норм Сімейного кодексу України, закріплених у ст. 1 завдань правового регулювання сімейних відносин, зокрема, утвердження почуття обов'язку перед батьками, дітьми та іншими членами сім'ї; забезпечення кожної дитини сімейним вихованням, можливістю духовного та фізичного розвитку. Вважаємо, шо виконанню цих завдань сприятимуть нещодавно прийняті Закон України «Про внесення змін до деяких законодавчих актів України щодо посилення захисту права дитини на належне утримання шляхом вдосконалення порядку примусового стягнення заборгованості зі сплати аліментів» та Закон України «Про внесення змін до деяких законодавчих актів України щодо створення економічних передумов для посилення захисту права дитини на належне утримання», Закон України «Про внесення змін до деяких законів України щодо посилення соціального захисту осіб, які доглядають за хворими дітьми». Аналізуючи зміни у процесуальному порядку стягнення аліментів, Ю. Некляєв наголошує, що результати внесення змін до чинного законодавства завжди знаходять своє відображення у правозастосовній практиці (насамперед у судовій), а досягнення позитивного результату дуже залежить від правильного та компетентного розуміння норм закону, а також якісної підготовки процесуальних документів для звернення до суду ${ }^{11}$. І. Апопій, досліджуючи новели вітчизняного законодавства щодо правового режиму аліментів, робить висновок про суттєві переваги внесених змін у законодавство, серед яких називає: конкретизацію розміру аліментів, спрощення порядку судового розгляду, суттєве зменшення можливостей приховування доходу і майна ${ }^{12}$.

СК України розділяє правові інститути, пов'язані з обов'язком з утримання залежно від суб'єкта утримання - дитини (гл. 15). другого 3 подружжя (гл. 9), батьків (гл. 17), інших членів сім'ї та родичів (гл. 22) та містить норми спеціального регулювання призначення утримання для кожного виду суб’єктів.

У питанні нарахування аліментів на дитину йдеться про забезпечення виконання батьками обов'язку утримувати дитину. Цьому правовому інституту присвячена гл. 15 СК України, що містить спеціальне пряме регулювання аліментних правовідносин, в яких суб'єктами виступають батьки та діти, але при визначенні розміру аліментів застосовується положення ст. 81 СК України, що відноситься до гл. 9 СК України з правового регулювання аліментних правовідносин дещо іншого суб'єктного складу, а саме: одного з подружжя на утримання. Попри це, Постанова КМУ № 146, до якої відсилає ст. 81 СК України, визначає необмежений суб' єктний склад учасників аліментних відносин.

Згідно з ч. 7 ст. 7 СК України дитина має бути забезпечена можливістю здійснення їі прав, установлених Конституцією України, Конвенцією про права дитини, іншими міжнародними договорами України, згода на обов'язковість яких надана Верховною Радою України, тому вважаємо, що при вирішенні питання розрахунку аліментів на дитину доцільно керуватися принципом здійснення регулювання сімейних відносин з максимально можливим урахуванням інтересів дитини (ч. 8 ст. 7 СК України) та виходити 3 ситуаційного контексту, на який вказує ч. 1 ст. 182 СК України «Обставини, які враховуються судом при визначенні розміру аліментів», де особливої уваги заслуговує п. 3-1 ч. 1 ст. 182 СК України, що зобов’язує суд враховувати наявність на праві власності, володіння та/або користування у платника аліментів майна та майнових прав, у тому числі рухомого та нерухомого майна, грошових коштів, виключних прав на результати інтелектуальної діяльності, корпоративних прав.

Висновки. Контекст понять «заробіток» і «дохід» в питанні нарахування аліментів доцільно розглядати крізь призму норм Сімейного кодексу України, закріплених у ст. 1 завдань правового регулювання сімейних відносин, зокрема, утвердження почуття обов'язку перед батьками, дітьми та іншими членами сім’ї; забезпечення кожної дитини сімейним вихованням, можливістю духовного та фізичного розвитку. Виходячи 3 погляду на питання нарахування аліментів на дитину крізь призму норм сімейно-правового регулювання, 3 урахуванням положень трудового, податкового законодавства, ст. 71 Закону України «Про виконавче провадження» та положень Постанови КМУ № 146, можна зробити висновок, що підхід до здійснення нарахування аліментів на дитину має базуватися на закріпленому у ч. 8 ст. 7 СК України принципі максимально можливого урахування інтересів дитини, тому до змісту поняття «заробіток» у ч.19 п. 1 Постанови КМУ № 146, до інших видів заробітку належать усі види заробітку (доходів), крім прямо обумовлених у законодавстві винятків. Вважаємо, що при вирішенні питання нарахування аліментів на дитину поняття «заробіток» і «дохід» слід розглядати керуючись принципом максимального забезпечення захисту прав дитини та застосовувати ситуаційний контекст обумовлений ч. 1 ст. 182 СК України та п. 3-1 ч. 1 ст. 182 СК України.

1 Чістякова І.М. Особливості розгляду судових справ щодо стягнення аліментів на дитину за участю іноземних громадян. Науковий збірник «Актуальні проблеми вітчизняної юриспруденції» Дніпровського національного університету імені Олеся Гончара. 2019. № 1. С. 70-74.

2 Ханович Є. Порядок стягнення аліментів на дитину за чинним законодавством. Підприємництво, господарство $і$ право. 2016. № 10. C. 20-25. URL: http://pgp-journal.kiev.ua/archive/2016/10/5.pdf

Часопис Київського університету права • 2019/3 
3 Перун С.В. Зміни до Сімейного кодексу України щодо сплати аліментів на дитину: нові розміри та порядок нарахування. Право, держава та громадянське суспільство в умовах системних реформ: матеріали III Міжнародної наук.-практ. конференції (м. Острог, 6-7 квітня 2018 р.). Херсон: Вид-во «Молодий вчений», 2018. 108 с. С. 65-68.

4 Свистун Л.Я. Правове регулювання стягнення аліментів на дітей. Право і суспільство. 2018. № 1. C. 88-94. URL: http://pravoisuspilstvo.org.ua/archive/2018/1_2018/part_1/18.pdf

5 Апопій І. Нові аспекти визначення розміру аліментів на дитину та їх стягнення. Підприємництво, господарство і право. 2018. № 9. C. 5-9. URL: http://pgp-journal.kiev.ua/archive/2018/9/2.pdf

6 Дайджест правових позицій Верховного Суду у сімейних спорах за I півріччя 2019 року / виконавці: Сандулєєва В., Куриленко Р., Нечипорук I. / НААУ Секція з сімейного права. 2019. URL: https://unba.org.ua/assets/uploads/files/Daydjest\%20pra vovih\%20pozitsiy\%20VS_Ukr\%20_SimeynihSporiv.pdf

7 Ухвала Колегії суддів Судової палати у цивільних справах Верховного Суду від 09.04.2008 p. URL: https://helsinki.org. ua/files/docs/1212664446.doc

${ }^{8}$ Свистун Л.Я. Правове регулювання стягнення аліментів на дітей. Право і суспільство. 2018. № 1. С. 88-94. C. 93. URL: http://pravoisuspilstvo.org.ua/archive/2018/1 2018/part 1/18.pdf

9 Дайджест правових позицій Верховного Суду у сімейних спорах за I півріччя 2019 року / виконавці: Сандулєєва В., Куриленко Р., Нечипорук I. НААУ Секція з сімейного права. 2019. С. 11. URL: https://unba.org.ua/assets/uploads/files/Daydjest\% 20pravovih\%20pozitsiy\%20VS_Ukr\%20_SimeynihSporiv.pdf

10 Шумило М. Допустимі межі поняття «заробітна плата» під час правозастосування: на шляху до єдності судової практики. Судово-юридична газета. 2019. 12 квітня. URL: https://sud.ua/ru/news/blog/137150-dopustimi-mezhi-ponyattya-zarobitnaplata-pid-chas-pravozastosuvannya-na-shlyakhu-do-yednosti-sudovoyi-praktiki

11 Некляєв Ю. Реалії судової практики: стягнення аліментів «по-новому». Юридична Газета. № 4-5. URL: http://yurgazeta.com/dumka-eksperta/realiyi-sudovoyi-praktiki-styagnennya-alimentiv-ponovomu.html

${ }_{12}$ Апопій І. Нові аспекти визначення розміру аліментів на дитину та їх стягнення. Підприємництво, господарство $i$ право. 2018. № 9. C. 8. URL: http://pgp-journal.kiev.ua/archive/2018/9/2.pdf

\title{
References:
}

Chistyakova, I.M. (2019). Osoblivosti rozglyadu sudovih sprav shodo styagnennya alimentiv na ditinu za uchastyu inozemnih gromadyan. Naukovij zbirnik «Aktualni problemi vitchiznyanoyi yurisprudenciyi» Dniprovskogo nacionalnogo universitetu imeni Olesya Gonchara. 1, 70-74 [in Ukrainian].

Hanovich, Ye. (2016). Poryadok styagnennya alimentiv na ditinu za chinnim zakonodavstvom. Pidpriyemnictvo, gospodarstvo $i$ pravo. 10, 20-25. URL: http://pgp-journal.kiev.ua/archive/2016/10/5.pdf [in Ukrainian].

Perun, S.V. (2018). Zmini do Simejnogo kodeksu Ukrayini shodo splati alimentiv na ditinu: novi rozmiri ta poryadok narahuvannya. Pravo, derzhava ta gromadyanske suspilstvo v umovah sistemnih reform. Materiali III Mizhnarodnoyi naukovo-praktichnoyi konferenciyi (m. Ostrog, 6-7 kvitnya 2018 roku). - Herson: Vidavnictvo «Molodij vchenij», 65-68 [in Ukrainian].

Svistun, L.Ya. (2018). Pravove regulyuvannya styagnennya alimentiv na ditej. Pravo i suspilstvo. 88-94. URL: http://pravoisuspilstvo.org.ua/archive/2018/1_2018/part_1/18.pdf [in Ukrainian].

Apopij, I. (2018). Novi aspekti viznachennya rozmiru alimentiv na ditinu ta yih styagnennya. Pidpriyemnictvo, gospodarstvo $i$ pravo. 9, 5-9. URL: http://pgp-journal.kiev.ua/archive/2018/9/2.pdf [in Ukrainian].

Sandulyeyeva, V., Kurilenko, R., Nechiporuk, I. (vikonavci) (2019). Dajdzhest pravovih pozicij Verhovnogo Sudu u simejnih sporah za I pivrichchya 2019 roku. NAAU Sekciya z simejnogo prava. 2019. URL: https://unba.org.ua/assets/uploads/files/Daydjest\% 20pravovih\%20pozitsiy\%20VS_Ukr\%20_SimeynihSporiv.pdf [in Ukrainian].

Uhvala Kolegiyi suddiv Sudovoyi palati u civilnih spravah Verhovnogo Sudu vid 09.04.2008 r. URL: https://helsinki.org.ua/ files/docs/1212664446.doc [in Ukrainian].

Svistun, L.Ya. (2018). Pravove regulyuvannya styagnennya alimentiv na ditej. Pravo i suspilstvo. 1, 93. URL: http://pravoisus pilstvo.org.ua/archive/2018/1_2018/part_1/18.pdf [in Ukrainian].

Shumilo, M. Dopustimi mezhi ponyattya «zarobitna plata» pid chas pravozastosuvannya: na shlyahu do yednosti sudovoyi praktiki. Sudovo-yuridichna gazeta. URL: https://sud.ua/ru/news/blog/137150-dopustimi-mezhi-ponyattya-zarobitna-plata-pid-chas-pravo zastosuvannya-na-shlyakhu-do-yednosti-sudovoyi-praktiki [in Ukrainian].

Neklyayev, Yu. Realiyi sudovoyi praktiki: styagnennya alimentiv «po-novomu». Yuridichna Gazeta. 4-5. URL: http://yur-gazeta. com/dumka-eksperta/realiyi-sudovoyi-praktiki-styagnennya-alimentiv-ponovomu.html [in Ukrainian].

Apopij, I. (2018). Novi aspekti viznachennya rozmiru alimentiv na ditinu ta yih styagnennya. Pidpriyemnictvo, gospodarstvo $i$ pravo. 9, 8. URL: http://pgp-journal.kiev.ua/archive/2018/9/2.pdf [in Ukrainian].

\section{Резюме}

\begin{abstract}
Атаманчук І.В., Ковальчук Ю.І. Межі розуміння понять «заробіток» і «дохід» у контексті правозастосування у відносинах стягнення аліментів.

У статті розглядаються поняття «заробіток» і «дохід» крізь призму сімейного законодавства, у відносинах стягнення аліментів. Акцентується увага на аналізі понять «заробіток» $\mathrm{i}$ «дохід», через фокус нормативної бази з регулювання захисту прав дітей, оскільки автори вважають, що у нашому суспільстві проблема належного матеріального забезпечення дітей стоїть найбільш гостро. Робиться висновок, що контекст понять «заробіток» і «дохід» у питанні нарахування аліментів доцільно розглядати крізь призму норм Сімейного кодексу України, закріплених у ст. 1 завдань правового регулювання сімейних відносин, а при вирішенні питання нарахування аліментів на дитину поняття «заробіток» і «дохід» слід тлумачити, керуючись принципом максимального забезпечення захисту прав дитини та застосовувати ситуаційний контекст, обумовлений ч. 1 ст. 182 СК України та п. 3-1 ч. 1 ст. 182 СК України.
\end{abstract}

Ключові слова: заробіток, дохід, права дитини, аліментні правовідносини, розрахунок аліментів. 


\section{Резюме}

Атаманчук И.В., Ковальчук Ю.И. Пределы понимания понятий «заработок» и «доход» в контексте правоприменения в отношениях взыскания алиментов.

В данной статье рассматриваются понятия «заработок» и «доход» через призму семейного законодательства в контексте правоприменения в отношениях взыскания алиментов. Акцентируется внимание на вопросах защиты алиментных прав детей. Делается вывод, что понятия «заработок» и «доход» в отношениях взыскания алиментов, следует трактовать через призму норм семейного законодательства

Ключевые слова: заработок, доход, права детей, алиментные правоотношения, расчет алиментов.

\section{Summary}

Irina Atamanchuk, Yuriy Kovalchuk. How to interpret terms "earnings" and "acuests" in the legal relations of penalty of alimonies.

In the article the questions of application of right are examined in the field of adjusting of penalty of alimonies through a court. Laws are analysed, legal norms of protection of rights for children in Ukraine. The concrete propositions to make the law regulations of alimental relations perfect and recommendations for the law enforcement bodies are made on the basis of the analysis of statutory and lawful acts of family-marriage law and court practice. On a way to European Union, for the Ukrainian state extraordinarily actual are decisions of problems of realization of right every child on education in family, increase in safe domestic surroundings, increase of efficiency of work of public organs and organs of local self-government from prevention of social orphanhood, perfection of the system of grant of social services to the children and families with children, providing of standard of living sufficient for physical, intellectual, moral, cultural, spiritual and social development of child.

The responsibilities of a married couples, parents and children, other relatives, person (guardian) who takes care of children in fact (the children themselves) are explained in a complex relations. The present article analyzes the latest innovations in national legislation regarding the legal regime governing the child maintenance, the process of determining the guaranteed and recommended minimum amount of child maintenance, circumstances to be taken into account in determining the amount of child maintenance, judicial consideration.

A child must be provided with possibility of realization of her rights set by Constitution of Ukraine, by Convention about rights for a child, by other international agreements of Ukraine. The authors of the article consider that at the decision of question of calculation of alimonies on a child it is expedient maximally to take into account interests of child. The legislation of Ukraine obligates a court to take into account a presence on the right of property, possession та/aбo use for the payer of alimonies of property and property rights, including the personal and immobile chattels, monetary resources, absolute titles on the results of intellectual activity, corporate laws.

The context of concepts "earnings" and "acuests" in the question of extra charge of alimonies it is expedient to examine through the prism of norms of the Domestic code of Ukraine. To the tasks of the legal adjusting of domestic relations belong: claim of call of duty before parents, children and other family members; providing of every child domestic education, possibility of spiritual and physical development. To maintenance a concept "earnings" belongs all types of earnings (acuests), except the exceptions straight conditioned in a legislation.

Key words: rights for a child, child support, family law relations, alimental obligation, extra charge of alimonies, a subject of alimental law relations.

DOI: 10.36695/2219-5521.3.2019.22

УДК 349.2

\section{Р.Я. БУТИНСЬКА}

Роксолана Ярославівна Бутинська, кандидат юридичних наук, старший викладач Львівського державного університету внутрішніх справ*

ORCID: 0000-0001-8492-2077

\section{ВПЛИВ ЦИФРОВИХ ТЕХНОЛОГІЙ НА ТРУДОВІ ВІДНОСИНИ: ВИКЛИКИ ТА ЗАВДАННЯ}

Постановка проблеми. В Україні розпочала роботу оціночна місія ЄС щодо єдиного цифрового ринку. Стратегія DSM нині успішно реалізується у Європі. На думку європейських експертів, єдиний цифровий ринок може принести об'єднаній Європі додаткові 415 млрд євро щороку й забезпечити створення сотень тисяч робочих місць. Стратегія спирається на європейські цінності справедливої та відкритої конкуренції, відкритого й безпечного Інтернету, який забезпечує вільний потік інформації. Це засвідчують такі факти: поперше, за кількістю користувачів мережею Інтернет вона займає одне з перших місць у Європі; по-друге, можливість доступу до мережі Інтернет з метою цифровізації економіки до 2024 р. має становити $97 \%$. Проблемою сучасного ринку праці стає цифровізація зайнятості, яка зумовлює не тільки появу і розширення

(C) Є.В. Бутинська, 2019

${ }^{*}$ Roksolana Butynska, Ph.D. in Law, Senior Lecturer of Lviv State University of Internal Affairs 